\title{
AN INVESTIGATION OF THE MOTIVATION OF HOTEL OWNERS AND OPERATORS TO ENGAGE IN EARNINGS MANAGEMENT
}

Dr Michael J. TURNER (corresponding author)

University of Queensland

UQ Business School

St. Lucia Campus

QLD 4072

AUSTRALIA

Phone: +61 733468071

Fax: +61 733468199

Email: m.turner@business.uq.edu.au

and

Professor Chris GUILDING

Griffith University

Griffith Business School

Gold Coast campus

QLD 4222

AUSTALIA 


\section{Structured Abstract}

Purpose - To empirically investigate the differential motivations of hotel owners and operators to engage in earnings management through the selective capitalisation or expensing of asset related expenditures.

Design/methodology/approach - Research evidence has been collected via a mixed methods approach utilising twenty semi-structured interviews with key hotel management contract stakeholders in Australia and a questionnaire survey administered to hotel general managers in Australia and New Zealand.

Findings - A review of the literature has resulted in an original distillation of 18 distinct earnings management motivations for hotel owners and operators. Qualitative data collected suggests an additional four motivations and that the primary motivation for hotel owners and operators to engage in earnings management stems from the two parties' desire to affect the size of the incentive management fee that is paid to hotel operators. A suggestion that operators have a greater tendency to seek to capitalise asset related expenditures, relative to owners, has been supported by both qualitative and quantitative data collected.

Practical implications - The study's findings signify that: (1) there is a continuing need for accounting standard setting bodies to further tighten capitalisation criteria, applied to asset related expenditures; (2) auditors should be aware of the earnings management motivation dynamics that play out between hotel owners and operators; (3) there is a continuing need for the preparers of the Uniform System of Accounts for the Lodging Industry to tighten criteria applying to the capitalisation of hotel asset related expenditures; (4) hotel operators should be alert to an apparent propensity of hotel owners to expense asset related expenditures; and (5) hotel owners should be alert to an apparent propensity of hotel operators to capitalise asset related expenditure.

Originality/value - This study appears to be the first to: (1) have examined the manner in which an idiosyncratic aspect of hotel governance can result in competing earnings management motivations between hotel owners and operators; (2) pursue a broad level of abstraction with respect to examining earnings management in the context of asset related expenditure capitalisation decision making; (3) assess the relative strength of earnings management motivations concerning the capitalisation or expensing of asset related expenditure; and (4) conduct earnings management research utilising a mixed methods research approach involving the conduct of face-to-face interviews as well as administration of a questionnaire survey. 
Keywords - Earnings management, generally accepted accounting principles, international financial reporting standards, asset, expense, hotel management contract.

Paper type - Research paper

Acknowledgement: This paper has benefitted from anonymous referee comments provided in the course of the paper's review process as well as attendee comments provided in seminars hosted by the Accounting, Banking \& Finance Department at the University of Canberra and the School of Accounting and Corporate Governance at the University of Tasmania. 


\section{AN INVESTIGATION OF THE MOTIVATION OF HOTEL OWNERS AND OPERATORS TO ENGAGE IN EARNINGS MANAGEMENT}

\section{Introduction}

The objective of this study is to empirically investigate the differential motivations of hotel owners and operators to engage in earnings management through the selective capitalisation or expensing of asset related expenditures. This issue has been investigated using a combination of field interviews and a mailed survey questionnaire.

Earnings management occurs when "managers use judgment in financial reporting and in structuring transactions to alter financial reports to either mislead some stakeholders about the underlying economic performance of the company or to influence contractual outcomes that depend on reported accounting numbers” (Healy \& Wahlen, 1999, p. 368). ${ }^{1}$ Earnings management is typically achieved by either: (1) structuring certain revenue and/or expense transactions; (2) implementing changed accounting procedures; or (3) manipulating accruals (McNichols \& Wilson, 1988; Mitra \& Rodrigue, 2002; Schipper, 1989).

Fundamental to this study is the extent to which subjectivity can be invoked when determining whether an asset related expenditure should be capitalised or expensed. If an expenditure is capitalised, the negative impact on profit is deferred in line with the depreciation schedule applicable to the asset in question. Manipulating the capitalisation of fixed asset related expenditures has been widely recognised as representing a significant source of much earnings management (Nelson, Elliott, \& Tarpley, 2003).

The scope for exercising subjectivity in a capitalisation decision stems from definition and recognition criteria for assets and expenses being somewhat loosely prescribed. There has been minimal tightening of criteria since the pertinent U.S. Generally Accepted Accounting Principle (GAAP) was described as "So complex, abstract, so open-ended, so all-inclusive, and so vague that we cannot use it to solve problems .... [the standard is] an empty box. A large empty box. A large empty box with sideboards. Almost everything or anything can fit into it” (Schuetze, 1993, p. 67). The lack of strong guidance from accounting standards signifies that "no allocation is completely defensible against other methods. For this reason

\footnotetext{
${ }^{1}$ Dechow and Skinner (2000) and Healy and Wahlen (1999) provide extensive reviews of the earnings management literature.
} 
all accounting allocations are, in the end, arbitrary” (Wolk, Dodd, \& Tearney, 2008, p. 378). When reporting according to International Financial Reporting Standards (IFRS), similar problems are encountered, as there is little difference in definition and recognition criteria for assets and expenses under the two systems. It is notable that the most frequently found attempts at earnings management occur when standards are imprecise or non-existent (Nelson, Elliott, \& Tarpley, 2002).

A significant body of earnings management literature exists concerning the capitalisation decision. Issues that have been addressed in this literature include: rate regulation (e.g. Linhart \& Lebowitz, 1974); research and development costs (e.g. Kamran \& Haim, 2006; Landry \& Callimaci, 2003; Lantz \& Sahut, 2005; Loudder \& Behn, 1995); exploration and development costs (e.g. Dhaliwal, Heninger, \& Hughes II, 1999; Iyengar, 1999; Styles \& Coe, 2001); interest costs resulting from capital investment (e.g. Bowen, Noreen, \& Lacey, 1981; Zimmer, 1986); depreciation charges (e.g. Lavely, 1983; Lee, Press, \& Choi, 2001); customer acquisition costs (e.g. Hyatt \& Weihrich, 2005); and manufacturing overheads (e.g. Noreen \& Bowen, 1989). Somewhat surprisingly, no prior empirical earnings management study has been conducted at a broad level of abstraction with a generic focus on asset related expenditure capitalisation decision making.

Much of the prior research on earnings management in the context of the capitalisation decision has made primary use of historical financial statement information (e.g. Dhaliwal, et al. 1999; Landry \& Callimaci, 2003; Lantz \& Sahut, 2005; Loudder \& Behn, 1995). Highlighting the distinctiveness of the study reported herein, an extensive literature search has failed to identify any prior studies concerning earnings management that have adopted a mixed methods research approach involving the conduct of face-to-face interviews followed by administration of a questionnaire survey. This observation is somewhat surprising, given the long-standing calls for more accounting research to be carried out in this manner (e.g. Birnberg, Shields, \& Young, 1990).

The remainder of the paper is organised as follows. The next section provides discussion of factors motivating the study's focus on the hotel industry. In the following section, earnings management motivations arising in the context of hotel management contracting are described by drawing on the literature. In subsequent sections, the mixed methods approach 
deployed is described and findings are presented. The final section provides a discussion and conclusion concerning issues arising from the study.

\section{Factors motivating the study's hotel sector focus}

A distinguishing facet of this study concerns its focus on a particular sector, the hotel industry. Three factors account for the hotel industry's selection for examination. An idiosyncratic facet of governance that is found in many hotels, provided the primary motivation for the study's hotel sector focus. Many hotels are governed by a management contract that sees the hotel owner engage the services of a specialist hotel operator to manage and operate the hotel (Contractor \& Kundu, 1998; Turner \& Guilding, 2010a). ${ }^{2}$ The relationship signifies that the owner (principal) retains full economic risk associated with ownership of the property, while the operator (agent) is responsible for the operation of the hotel (Schlup, 2004). The separation of ownership and control creates an agency relationship between the owner and operator (Dimou, Chen, \& Archer, 2003). An agency relationship arises when one party (the principal) appoints another party (the agent) to perform some service on its behalf (Jensen \& Meckling, 1976). Motivations to manage earnings manifest in the context of agency relationships (Jensen \& Meckling, 1976). As will be shown below, the most widely used approach for determining a hotel operator's remuneration is based on a hotel's reported sales and profit. This signifies a potential for conflicting interests between the two contracting parties with respect to the determination of reported profit. Table 1 outlines the manner in which the perspectives of hotel owners and operators diverge.

\section{INSERT TABLE 1 ABOUT HERE}

The second factor motivating the study's focus on the hotel industry relates to the capital intensive nature of hotels (Collier \& Gregory, 1995; Guilding \& Hargreaves, 2003). In a study by the International Society of Hospitality Consultants (ISHC) of asset related expenditures made by U.S. hotels in the period 2000-2005, annual capital expenditure was found to be $5.4 \%$ of gross revenue, while annual repair and maintenance expense constituted 3.6\% of gross revenue (ISHC, 2007). Consequently, total asset related expenditure represents

\footnotetext{
${ }^{2}$ A range of organisations and individuals own hotels. Examples of hotel owners include real estate investment trusts, mutual funds, investment banks, insurance companies, superannuation funds, property developers and high net worth private investors. Hotel operating companies include Accor Hotels (with brands such as Sofitel, Mercure and Novotel); Intercontinental Hotels Group (with brands such as Intercontinental, Crowne Plaza and Holiday Inn); and Starwood Hotels and Resorts (with brands such as Meriden, FourPoints, and Westin).
} 
approximately 9\% of gross revenue, or U.S.\$7,884 per room per annum during the 20002005 period (ISHC, 2007). The decision to capitalise or expense an asset related expenditure item can therefore have a profound effect on the reported operating performance of a hotel (Phillips, 2003).

The third factor accounting for the study's hotel industry focus relates to the sector's apparent particular struggle with respect to defining what constitutes capital expenditure. Sixty-two percent of hoteliers in the U.S. are often unsure about whether to expense or capitalise an item and over $72 \%$ of hoteliers would welcome greater guidance on the issue (Schmidgall, Damitio, \& Singh, 1997). Widespread confusion remains despite the industry providing additional guidance through the Uniform System of Accounts for the Lodging Industry (USALI), which is based on recommendations from senior lodging industry financial executives, public accounting authorities and leading academic experts. The USALI (1996, p. 205) notes that much expenditure associated with activities such as property development, construction and renovation are often expensed when they should be capitalised. Consistent with accounting standard shortcomings, hotel executives have achieved limited consensus on the criteria by which asset related expenditure should be capitalised (Denton \& Yiankes, 2004; Schmidgall, et al. 1997). Prior research has found that a financial controller's determination of whether an asset related expenditure should be capitalised is frequently heavily influenced by directions provided by a hotel owner or the operating company's senior management (Schmidgall, Damitio, Duffy, \& Singh, 1998).

As a final comment, it is pertinent to make explicitly clear in whose financial statements items of asset related expenditure are capitalised or expensed. On this issue, the entry concerning the capitalisation or expensing of an item of asset related expenditure is made in the books of the owner, not the operator. This is because under the management contractual arrangement, the hotel owner retains full legal ownership of the hotel site, building, plant and equipment, furnishings and inventories, while the operator is responsible for the day to day business of the hotel (Guilding, 2003). A second point worth clarifying relates to whose responsibility it is to make decisions around whether an item is expensed or capitalised. An earlier study conducted by the research team saw hotel managers provide several illustrations of the way in which hotel management can influence how an expenditure is recorded. One particular approach involves influencing the nature of an expenditure. For example, if replacing a couple of boardroom chairs, which would ordinarily be expensed, hotel 
management may well endeavour to persuade the owner of the merits of replacing all of the boardroom chairs. The decision to replace thirty, as opposed to two, chairs would likely move the expenditure across the capitalisation threshold. A further example provided by hotel management was how to deal with a leak in a wall. The leak could be approached by taking a repeated 'patch up’ maintenance approach (which would be expensed), or hotel management might well strongly promote the idea of undertaking more significant building structure rectification (which would be capitalised). These examples underscore the capacity of hotel management to influence the relative size of a hotel's expensed versus capitalised expenditure.

\section{Earnings management motivations in the context of hotel management contracting}

In this section, we categorise earnings management motivations drawn from the literature according to whether they motivate a hotel owner to capitalise asset related expenditure or expense it, or whether they motivate a hotel operator to capitalise asset related expenditure or expense it.

\section{Factors motivating a hotel owner to capitalise asset related expenditure}

A first motivation is to bloat the value of assets reported in the balance sheet. Hirshleifer, Kewei, Teoh and Yinglei (2004) note that some investors view balance sheet information as more important when evaluating an entity than corresponding information in the income statement. A distinctive role of the balance sheet is also to facilitate loan decisions and monitoring of debt contracts. It fulfils this role by providing information on liquidation values (Watts, 1974). Allison (2004) observes that some hotel buyers attach particular significance to high balance sheet asset values. Bloating reported asset values may therefore potentially boost a hotel-owning company's share prices. A desire to inflate reported asset values may also result from the fact that most bankers and lenders will only lend between 70 and 90 percent of the appraised value of a hotel property (Hotel Brokers International, 2001, 2005). In addition, many lenders lend against a certain percentage of a property's book value (Hotel Brokers International, 2001, 2005). While this motivation is inconsistent with semi-strong form efficient market theories, suggesting investors are able to see through such paper entries (Ross, Westerfield, \& Jordan, 2001), it should be noted that the semi-strong form efficiency theory has been challenged both theoretically and empirically (see e.g. Barberis, Shleifer, \& Vishny, 1998; Beaver \& Engel, 1996; Daniel, Hirshleifer, \& Subramanyam, 1998). One branch of recent research now suggests that a negative relationship between high balance 
sheet values and stock returns is sometimes observed (e.g. Chan, Karceski, Lakonishok, \& Sougiannis, 2008; Cooper, Gulen, \& Schill, 2008; Lipson, Mortal, \& Schill, 2009).

A second motivation relates to a focus on curtailing an operator's propensity for overbuilding. Rushmore (1998) claims that since the early 1970s, many hotel owners have lost money from overbuilding. In an attempt to lessen the propensity for overbuilding, an owner may seek to fund non-furniture, fittings, and equipment (FF\&E) expenditures from the $F F \& E$ reserve fund. The FF\&E reserve is an account intended for operator use to fund FF\&E capital expenditure (Turner \& Guilding, 2010a). This strategy depletes the FF\&E reserve fund, thereby restricting the operator's capacity to engage in overbuilding. Turner and Guilding (2010a) found that in hotels mediated by a management contract, it is common for the owner to be required to contribute around three per cent of gross revenue to the FF\&E reserve.

A third motivation relates to satisfying debt covenants to avoid property foreclosure. This is because capitalisation can enhance the debt-coverage ratio, which can make a hotel appear more capable of meeting its interest and principal payments on debt. ${ }^{3}$ This can be important in securing additional funding from bankers and lenders (Farlex, 2006; Hotel Brokers International, 2001, 2005).

A fourth motivation derives from a desire to demonstrate to a potential buyer that a hotel has undergone a recent high capital expenditure programme. This can serve to demonstrate that the hotel is in a good condition and will require only low levels of capital expenditure in the short-term, which may help facilitate an easier and potentially higher priced sale (Pinkowski, 1995).

A fifth motivation concerns a potential desire to achieve income smoothing in order to project an appearance of consistent earnings growth (Michelson, Jordan-Wagner, \& Wootton, 2000; Scott, 2003; Tucker \& Zarowin, 2006). Accordingly, in a year of low hotel profitability, an owner may seek to capitalise asset related expenditure that might otherwise have been expensed. While the converse is also the case, the incentive to expense in a year of high hotel profitability has not been identified as a separate factor in the next section.

\footnotetext{
${ }^{3}$ The debt-coverage ratio is typically calculated by dividing the net operating income (NOI) by a property's annual debt service (i.e. interest expense).
} 


\section{Factors motivating a hotel owner to expense asset related expenditure}

The first motivation arises in connection with the way that an operator's remuneration is determined. In a hotel management contract, the operator's remuneration is widely referred to as a 'management fee' (Rushmore, 2002). Three basic management fee structures are found in practice: (1) a base fee only; (2) an incentive fee only; or (3) a base fee combined with an incentive fee (Goddard \& Standish-Wilkinson, 2002). The combination of a base and incentive fee is the most common (Eyster, 1993). With regard to the incentive fee, the most common is based on a percentage (usually around 10\%) of the hotel's Gross Operating Profit (GOP) (see Turner \& Guilding, 2010b). The owner's motivation to expense is to lower GOP and therefore reduce the operator's incentive fee remuneration.

A second motivation stems from a desire to reduce reported profit in order to minimise tax payable in a particular period. The time value of money signifies that current tax deductions are more valuable than deductions in later accounting periods (Guenther, 1994; Healy \& Wahlen, 1999; Scott, 2003). The ability to pursue this motivation is somewhat constrained, however, by the fact that tax write-offs should adhere to taxation authority rules.

A third motivation derives from a desire to demonstrate to potential buyers that a hotel that is for sale requires only low capital expenditure. An expectation of lower future capital expenditures is consistent with a hotel commanding a higher selling price (Niehaus, 2008).

A fourth motivation concerns a potential desire to invoke a management contract termination provision. If a hotel operator fails to achieve a profit threshold that is identified in its management contract, a termination clause can be invoked (see Turner \& Guilding, 2010b).

\section{Factors motivating a hotel operator to capitalise asset related expenditure}

As noted above, Turner and Guilding (2010b) explain that hotel operators' incentive fees are typically based on the GOP achieved by the hotel that they manage. This signifies a propensity of hotel operators to seek to capitalise asset related expenditure, in order to increase reported GOP and, in turn, the incentive fee received by the operator.

A second motivation relates to the potential desire to smooth income (Scott, 2003). In a year of low hotel profitability, an operator may seek to capitalise (Michelson, et al. 2000; Scott, 
2003; Tucker \& Zarowin, 2006). Likewise, in a year of high hotel profitability an operator may seek to capitalise (Scott, 2003).

\section{Factors motivating a hotel operator to expense asset related expenditure}

The first motivation concerns the case where an FF\&E reserve balance is insufficient to support necessary FF\&E expenditure to maintain a hotel's brand standard (Ransley \& Ingram, 2001; Rushmore, 2002). Once an FF\&E reserve has been fully depleted, a hotel operator that is intent on making further FF\&E related asset expenditures may attempt to expense the expenditure. Turner and Guilding (2010a) identified a tendency for FF\&E reserves to be significantly underfunded.

Somewhat relatedly, a second motivation concerns a potential desire to leave funds in the FF\&E reserve (Eyster, 1997). This motivation will be particularly apparent when the amount in the FF\&E reserve is just enough to fund the planned purchase of a large FF\&E item and any diminution of the fund will prevent the planned purchase from proceeding.

A third motivation can arise from a desire to bypass the need to gain owner approval for a planned capital expenditure. Guilding (2003) observed that hotel capital budgeting systems typically involve operators initiating capital investment proposals prior to an owner determining which expenditure proposals will be undertaken. If an operator is seeking for an asset related expenditure to be made expeditiously, they may try to circumvent the capital budgeting process by expensing the expenditure.

A fourth motivation is to gain reimbursement for repair and maintenance expense. Schlup (2004) explains that in a small number of management contractual arrangements, minor repair and maintenance costs are regarded as an operating expense that the owner should reimburse to the operator. Such a contractual arrangement provides an operator with an incentive to expense asset related expenditures.

A fifth motivation relates to a desire to manipulate GOP between minimum and maximum thresholds in order to trigger higher incentive management fees. This motivation relates to Healy's (1985) bogeys (minimum bonus) and caps (maximum bonus). If it appears likely that GOP for a year will exceed an operator's cap, the operator will have an incentive to engage in profit decreasing actions in order to increase reported GOP in subsequent accounting periods. 
Similarly, if it appears likely that GOP for a year will fall beneath the bogey, the operator might be motivated to 'take a bath' by expensing as much asset related expenditure as possible (Scott, 2003).

A sixth factor that may cause an operator to seek the expensing of asset related expenditures arises when an operator wants to circumvent the need to gain owner approval in a situation of capital budget expenditure limits being exceeded. Variations above budgeted capital expenditure levels place a particular onus on the operator to justify the over-budget expenditure (Mukherjee \& Henderson, 1987).

\section{Methodology}

The study's research objective of empirically investigating the differential motivations of hotel owners and operators to engage in earnings management through the selective capitalisation or expensing of asset related expenditures has been executed through the conduct of face-to-face interviews followed by the distribution of a mailed questionnaire survey. This sequence of empirical data collection signifies the application of a mixed methods approach. This provides a form of data triangulation, because the weaknesses of one approach can be compensated for by the strengths of the other approach (Birnberg, et al. 1990; Miles \& Huberman, 1994; Model, 2010; Rossman \& Wilson, 1984, 1991). It has been widely recognised that the combination of face-to-face interviews and a mailed questionnaire survey can enhance a study’s reliability and validity (Abernethy, Chua, Luckett, \& Selto, 1999; Miles \& Huberman, 1994; Sutton \& Rafaeli, 1998).

Face-to-face interviews carry a range of strengths. One of the most important is that they enable a researcher to probe deeply to uncover new clues to and dimensions of a problem, and to secure context sensitive, vivid accounts resulting from the researcher meeting with subjects (Aherns \& Dent, 1998; Bailey, 1996; Yin, 2002). The interview method does, however, have weaknesses. Perhaps the most prominent is interviewer bias, which occurs when an interviewer imposes their own opinions and attitudes on an interviewee and on how an interviewee's perspectives are interpreted. This can greatly affect the manner of the information collected and also reported observations (Lillis, 1999). Although bias can never be overcome completely, steps can be taken to minimise its potential (Saunders, Lewis, \& Thornhill, 2003). One such step, the use of open-ended questions that facilitate interviewees answering in their own words (Easterby-Smith, Thorpe, \& Lowe, 2002), was adopted in this 
study. In addition, considerable care has been taken to fairly reflect the views expressed by the interviewees.

With respect to the mailed questionnaire phase of empirical data collection, it is noteworthy that mailed questionnaires have been used prolifically in accounting research over the last twenty-five years (Chapman, Hopwood, \& Shields, 2007). A significant shortcoming associated with this form of data collection relates to low response rates (Neuman, 2003). In an effort to promote a high response rate, considerable care was taken to develop a questionnaire with a professional and user friendly appearance (Smith, 2003), and, as will be evident from the survey administration procedures described below, considerable effort has been expended in making repeated approaches to the target sample (Roberts, 1999; Young, 1996).

\section{Exploratory interview phase}

\section{Exploratory interview method applied}

The study's first empirical phase involved the conduct of exploratory interviews. Interviews were conducted with 20 Australian hotel industry experts. All interviews were conducted in a face-to-face setting at the participants' places of work. To provide scope for gauging a broad range of perceptions on the issues under examination, the interviewee sample represented six stakeholder groups: six asset managers, two hotel management contract lawyers, two hotel auditors, three hotel owner representatives, four hotel general managers and three hotel financial controllers. The research team maintains close contacts with the hotel sector, and three large hotel management consulting companies endorsed the study and provided the names of individuals whose experience signified that they were well placed to provide insights concerning the issues under examination. Also, the initial interviewees provided further strong leads enabling the research team to expand the potential interviewees approached. Upon completion of the interviews, the interviewees were able to provide informed suggestions concerning other hotel sector professionals who could usefully act as interview subjects. Twenty-five potential interviewees were contacted. Initial contact was achieved via the mailing of an interview package that included information aimed at stimulating interest in the study and informing potential participants that they would shortly be receiving a phone call from the research team to explore the possibility of their participation in the study. Twenty of the contacts agreed to be interviewed. Of the five contacts who did not wish to participate, three cited the problem of lengthy overseas 
commitments and two indicated a lack of available time. Theoretical convergence (Yin, 2002) was evident after the completion of the 20 interviews.

Given the nature of the data sought, a semi-structured interactive data collection interview protocol was adopted. The inclusion of some open-ended questions was thought to be particularly important in order to reduce potential bias from the researchers imposing opinions, attitudes or answers onto the interviewees (Easterby-Smith, et al. 2002). Interviewees were invited to provide their 'general' perceptions rather than restrict their observations to insights secured in the context of their current employment. Many of the interviewees had accumulated more than 25 years of experience within the hotel industry, and hotel sector job mobility is notoriously high (Akrivos, Ladkin, \& Reklitis, 2007). The interview schedule was structured in a manner that initially gauged the frequency that subjectivity is invoked when electing to capitalise or expense an asset related expenditure. Next, the pertinence of the 18 earnings management motivations identified from the literature review above was assessed. The interviewees were encouraged to comment on the strength of each motivation and to describe any additional earnings management motivations relating to asset related accounting treatments.

\section{Exploratory interview data findings}

Supporting claims made in the literature (Wolk, et al. 2008, p. 378), early in the conduct of the interviews it became apparent that while some asset related expenditures clearly qualify to be expensed and others clearly warrant capitalisation, there are many others occupying a large discretionary area, signifying considerable scope for earnings management. An asset manager commented:

There is that slice of gray. There is obvious capital and there is obvious expense, but it's that stuff in the middle that's the problem.

It was widely-held by the interviewees that accounting standards provide little in terms of delimiting the extent to which discretion has to be exercised for a large volume of hotel asset related expenditures. For example, one of the lawyers interviewed commented:

You have the accounting standards to help you, but I think that they don't work. This is illustrated by the wide variety of ways that the different operators classify things. This suggests little has changed since Schuetze (1993) heavily criticised accounting standards of failing to provide sufficient guidance with respect to which asset related expenditures 
should be capitalised and which should be expensed. Further support for the view that accounting standards are deficient in terms of mitigating the scope for discretionary accounting judgement is evident in the following comments provided by a financial controller:

Based on the accounting standards, one person's interpretation of it might be that it is a repair and maintenance expense and another person's interpretation might be that it is a capital cost and both could technically be correct.

The view that accounting standards offer considerable scope for hotel accountants to engage in earnings management in the area of accounting for asset related expenditures was widely held by the interviewees. Examples of expenditures that were seen to commonly fall into the grey arbitrary area between clear expensing or capitalisation included: (1) expenditure made to the base structure of a hotel building; (2) cosmetic upgrades to lifts; (3) partial replacement of a wall; (4) upgrading hardwired internet connections; and (5) upgrading rooms from conventional to flat screen televisions. One interviewee captured the essence of the arbitrariness that can arise when electing whether to capitalise or expense by posing the question:

How many new bricks do you have to put into an existing wall before you cease to be repairing the wall and are converting it into a replacement wall?

In a similar manner that focuses on the quantum threshold of expenditure signifying qualification for capitalisation, a general manager commented:

If we replace the entire trolley it's probably CapEx, but what if we keep the wheels and replace everything else, we are repairing it, we are not buying a new one!

In terms of the likelihood of accounting authorities being able to lessen the degree of judgement invoked when determining how asset related expenditures should be accounted for, it was illuminating to discover a lawyer responsible for drafting hotel management contracts having grown somewhat cynical of the quest for more tightly defined criteria. One of the interviewed lawyers commented:

It is very hard to try and draft a management contract that can clearly differentiate how to treat asset related expenditure. I must say that over the last ten years there has been a lot less attention given to trying to create an absolute black and white differentiation because it is not possible. It's a question of degree. It's sort of like 
pornography, it's hard to define, but when you see it, you know what it is. It's that sort of thing.

This observation is particularly noteworthy because it has not been reported in the prior literature that delineation of how asset related expenditures are to be accounted has found its way into management contract clauses. This interviewee's comments provide a strong basis for expecting widespread manipulation of the capitalisation decision in the hotel context. Following a broad discussion of challenges associated with accounting for asset related expenditure, interviewees were introduced to the distinct motivations for owners and operators to expense or capitalise asset related expenditure that were outlined earlier.

The motivations provided to the interviewees are presented in the first column of Tables 2, 3, 4 and 5. These tables also provide the additional motivations advanced by the interviewees (appearing in the lower panel and prefaced by the word "New"). The second column in the tables provides an indication of the strength of the motivation apparent from comments made by the interviewees. It should be acknowledged that a degree of subjectivity is bound to be invoked when assigning a global rating that reflects the views of the 20 interviewees. ${ }^{4}$ The third column provides a generic consolidation of the views expressed by the interviewees.

\section{INSERT TABLES 2 - 5 ABOUT HERE}

It was observed that the strongest earnings management motivations relate to the determination of an operator's incentive management fee, which is consistent with the view that agents' most common incentive to engage in earnings management stems from compensation issues (Nelson, et al. 2002). Strong support for the view that owners seek to expense asset related expenditure to reduce the GOP-determined incentive management fee, while operators seek to capitalise asset related expenditure for the reciprocal reason was in evidence. Consistent with this, an asset manager commented:

An operator obviously wants to capitalise it somehow, because they don't want the cost hitting the profit and loss statement as this will reduce their incentive fee, but an owner will be focused the other way.

\footnotetext{
${ }^{4}$ It was felt inappropriate to attempt the collection and analysis of quantified data through the use of measurement instruments such as Likert scales. Given the limited sample size, any provision of summary statistics would carry the risk of imparting a misleading air of data robustness and reliability.
} 
Another illuminating comment that supported the view that earnings management motivations derive from the operator incentive management fee issue was provided by another asset manager who commented:

The first thing that an operator will think about before making a decision is 'is this going to cost us any money out of our management fees?' From the operator's point of view, every dollar that they permit to go into the repairs and maintenance in the profit and loss statement reduces the GOP and therefore reduces their incentive fee, so it really does reduce down to this. It's an accounting determination and they want to push everything to be capitalised because it doesn't affect the GOP and therefore increases their incentive fee.

In addition to the focus on the operator's fee determination, the following comment provided by an asset manager points to broader dynamics in the owner-operator relationship and an operator's desire to avoid termination clauses being invoked in the manner noted by Turner and Guilding (2010b):

Operators also like to capitalise, not only for the incentive fee benefit but also because it can affect performance hurdles or performance termination rights that the operator might have beyond fees, so an operator will always be focused that way ... an owner will be focused the opposite way.

While some might be dismissive of the tax write-off consideration due to taxation rulings adopted by taxation authorities, it was notable that some practitioners feel that the tax management incentive described by Scott (2003) is in evidence in the context of asset related expenditure accounting. Supporting this view, a lawyer commented:

From an operational point of view, a major motivation for hotel owners will be to do with taxation consequences, so he probably wants to have a big repairs and maintenance budget so he can expense these and theoretically benefit for taxation purposes.

The significance of the role of debt covenants (Hotel Brokers International, 2001, 2005) affecting owners' preference to capitalise asset related expenditures was also in evidence. One of the interviewed asset managers commented:

Sometimes the owner won't want to expense because they might breach covenants on debt. You will also find that most owners will want to push the asset related 
expenditure into a capital cost from the FF\&E reserve so that it gets this reserve used up and then they can have full control over any additional capital spending.

Supporting the significance of FF\&E reserve accounting noted by Turner and Guilding (2010a), it was noted that operators feel strongly motivated to pursue accounting strategies that are consistent with preserving their FF\&E reserve. This is apparent from the following observation by an asset manager:

Before making a decision, the second question an operator asks is 'will this affect our FF\&E reserve?' If it does, the operator will immediately look at ways to either expense the cost as repairs and maintenance or to push it to an owner capital cost, which is not funded from the FF\&E reserve.

An observed earnings management motivation that was not found in the literature search concerned the fact that in many management contracts, the legal responsibility for projects that are expensed as repairs and maintenance rests with the operator. For asset related expenditures that are capitalised, the legal responsibility falls on the owner. An asset manager commented:

Another reason why the operators want to belt it into capital instead of repairs and maintenance expense is that if the issue is fundamental, such as replacing the lifts, the operator doesn't want to know about it because it is not part of their responsibility. So they say "We're here to run the business side of the hotel, not the hotel property. So 'a' we don't have any expertise in the area, and 'b' we don't want to waste any of our time doing the owners job”. Therefore we want the cost capitalised to shift responsibility to the owner. The reverse of this could also be said for the owner.

This issue would appear to be the cause of considerable potential friction between hotel owners and operators and appears worthy of more detailed examination in any future study that focuses on the challenging dimensions of the hotel owner-operator relationship.

A further motivation for hotel owners to capitalise asset related expenditure that had not been anticipated or identified from the literature was raised by an owners' representative, who commented:

I think from an owner's perspective, I feel most of the time they are inclined to capitalise rather than expense because they want to increase yields. For example, if 
you increase your profits by capitalising, it gives you higher yields, whereas if you expensed and took money out of profit it would result in lower yields on investment.

This particular form of earnings management is not peculiar to the hotel sector.

\section{Questionnaire survey phase}

In light of the strong qualitative data suggestion that hotel owners have a tendency to promote the expensing of asset related expenditure while operators are predisposed to promoting the capitalisation of asset related expenditure, survey data has been collected to further explore the potential for conflicting earnings management motivations between the two parties.

\section{Sampling procedure}

A mailed questionnaire survey was sent to general managers in Australian and New Zealand hotels with twenty or more rooms and a minimum star-rating of three. The 2006/2007 Royal Automobile Club of Queensland (RACQ) Hotel Accommodation Guide provided the sampling frame for the Australian sub-sample. The New Zealand sub-sample was compiled from two extensive online databases: ‘wotif.com' and 'asiahotels.com'. This provided a total sample size of 664, comprising 463 Australian hotels and 201 New Zealand hotels. As there is no database that is restricted to hotels operating with a management contract, the questionnaire included a screening question designed to determine whether the respondent's hotel operated with a management contract. Three weeks subsequent to the initial mailing, a follow-up mailing was sent to the entire sample frame. Two weeks after the second mailing, a number of hotel owner representatives familiar to the research team agreed to circulate the questionnaire to general managers with whom they had close contact. This generated a further 51 responses. Two weeks subsequent to the owner representatives' distribution of questionnaires, the sample was contacted by email and encouraged to complete the questionnaire which was provided as an attachment. Finally, two weeks after the email approach, random telephone calls were made to a number of general managers. The objective of these phone calls was threefold: to thank the general manager if they had already completed the survey; to ascertain the main reasons for non-participation in the study; and to encourage participation in the study. Non-response reasons provided by the hotels contacted by phone included "completing questionnaires contravenes company policy”, "too busy” and "the general manager was away on holiday". No factors cited suggested the presence of any systematic non-response bias. An investigation for profile differences between the first mailing respondents and the remainder of the respondents was also undertaken and no 
differences were noted. Forty one hotels were excluded from the sampling frame due to the hotel either not existing or the respondent indicating that it was against company policy to complete questionnaires. A summary of the survey response pattern is provided in Table 6 .

\section{INSERT TABLE 6 ABOUT HERE}

\section{Development of questionnaire measures}

No prior survey measures designed to gauge hotel accounting treatment of asset related expenditure have been found in the literature. Prior earnings management research concerning ethical issues (e.g. Jackling, Cooper, Leung, \& Dellaportas, 2007), managerial attempts at earnings management (e.g. Nelson, et al. 2003), the acceptability of earnings management (e.g. Clikeman, Geiger, \& O'Connell, 2001) and factors influencing managers to undertake earnings management (e.g. Tzovas, 2006) have developed scenarios to appraise earnings management tendencies. Following this lead, a contextually-based scenario was developed for the questionnaire respondents. The questionnaire included the following statement and two ensuing questions:

A degree of subjectivity can be called for in determining whether asset related expenditure is capitalised (i.e. placed on the balance sheet as an asset) or expensed (i.e. placed on the profit and loss statement as an expense). Where this uncertainty arises:

(1) To what extent does the owner of your hotel seek to capitalise the item?

(2) To what extent does your operating company to seek to capitalise the item?

For both questions, a seven-point Likert scale was provided where 1 corresponded to "not at all” and 7 corresponded to "to a large extent”.

\section{Survey findings}

A paired samples t-test was undertaken to investigate whether there was any statistically significant difference between the data collected for these two questions. It was found that operators are perceived to have a statistically significantly greater propensity to capitalise asset related expenditure $($ mean $=4.54$, standard deviation $=1.47)$ compared to owners $($ mean $=3.94$, standard deviation $=1.66), t(96)=-2.947, p<.05$. Summary statistics yielded by the study's survey phase are presented in Table 7. 
The finding that operators have a statistically significantly greater propensity to capitalise asset related expenditure provides quantitative support to observations made during the interview phase of the study. It is consistent with the view that operators have a lesser propensity to seek the expensing of asset related expenditures relative to owners.

\section{Discussion and Conclusion}

The objective of this study has been to examine the relative motivations of hotel owners and operators to engage in earnings management through selective capitalisation or expensing of asset related expenditures. The motivation for conducting the study derived from several sources. Firstly, no prior empirical earnings management study, conducted at a broad level of abstraction with a generic focus on asset related expenditure capitalisation decision making, has been found in the literature. Secondly, the majority of prior research concerning instances of earnings management carried out through the structuring of revenue and expense transactions has been based primarily on historical financial statement information (secondary data), rather than the collection and analysis of primary data, as was undertaken in this study. Thirdly, hotel management contracts give rise to a particular form of agency relationship between owner and operator that to date has received little research attention, despite the idiosyncratic nature of the issues presented by the relationship and the significant agency issues that they raise. Finally, prior research suggests that the hotel industry experiences a particular struggle in defining what qualifies as a capital expenditure item. These motivations flag the manner and extent of the study's distinctiveness and novelty.

The literature review undertaken in advance of empirical data collection enabled an original distillation of 18 distinct motivations for hotel owners and operators to engage in earnings management by electing to expense or capitalise an asset related expenditure where a degree of accounting discretion arises. Observations made in the interview phase of this study suggest that this listing can be augmented by an additional four distinct motivations. Identification of these 'new' earnings management motivations constitutes an original contribution to the earnings management literature.

The primary finding of the study's exploratory interview phase concerns the strong suggestion that hotel owners and operators extensively engage in earnings management by selectively capitalising and expensing asset related expenditures. The strongest motivation for 
this revolves around the widely used operator incentive management fee that is profit based. It has been found that owners are motivated to expense asset related expenditure in order to reduce the GOP-based operator incentive management fee and that operators are motivated to capitalise asset related expenditure in order to increase the fee. In light of this finding, a statistical examination was made of the extent to which hotel owners seek to capitalise asset related expenditure relative to operators. This analysis revealed a perception by general managers that owners are more likely to seek to capitalise asset related expenditures than hotel operators. This finding lends credibility to the observations made during the interview phase of the study.

When considering the implications of this finding for other industrial settings, it appears particularly pertinent to consider those organisational contexts where the remuneration of managers is tied to reported profit levels. Insights obtained from the study reported herein would suggest that in such settings, if a manager exercises influence over the way that asset related expenditures are accounted for, there is likely to be an incidence of earnings management pursued by means of accounting for asset related expenditures in a way that maximises managers' remuneration. This suggests that auditors should be particularly on their guard when confronted by the following three contingencies: (1) management remuneration is linked to reported profit levels; (2) these managers have a capacity to influence how asset related expenditures are accounted for; and (3) a high incidence of asset related expenditures that gives rise to discretion being exercised in connection with whether the expenditures should be capitalised or expensed.

A further implication of the study's findings is that they highlight the importance of accounting standard setting bodies such as the International Accounting Standards Board (IASB), Australian Accounting Standards Board (AASB), and the Securities Exchange Commission (SEC) continuing to direct considerable endeavour to more tightly defining when an asset related expenditure should be expensed and when it should be capitalised and what should be expensed. Likewise, the study should alert hotel industry bodies such as the American Hotel and Lodging Association, which prepares the USALI, to develop hotelspecific criteria to lessen the exercise of discretion when accounting for asset related expenditures. Further, hotel bodies in countries adopting International Accounting Standards, such as the Australian Hotels Association, may interpret the study's findings as providing a strong case for the development of a comparable publication to the USALI that is based on 
IASs, rather than the U.S. GAAP. Finally the study's findings highlight the need for designers of hotel management contracts to direct attention to carefully delineating what expenditures qualify to be capitalised.

Current and prospective hotel owners may find the study particularly illuminating in terms of developing their appreciation of the propensity of operators to indulge in earnings management. Such an understanding may better equip hotel owners to mitigate potential agency problems. The study's findings also suggest that for a hotel owner-operator relationship to be successful over a protracted period, considerable care will need to be directed to managing the conflicting earnings management incentives of the two contracting parties.

In framing this study, agency theory and the related earnings management literature have been drawn upon. It is pertinent to note, however, that personal traits of hotel managers can be expected to result in differences in the extent to which they engage in self-serving actions. As a result, it could be revealing to conduct an asset related expenditure study informed by the decision psychology literature. This literature highlights the importance of individual character traits and how they have a bearing on the extent to which a responsible decision is made (Zsolnai, 2003). The extent to which a decision-maker is likely to make a responsible decision draws upon the theory of 'prospective moral responsibility' first presented by Jonas $(1979,1984)$.

Probably the greatest contribution of this study stems from its originality. As a research forerunner, it is to be expected that further related research will follow. The study has exposed specific earnings management issues arising from the particular parameters of an owner-manager dynamic that is peculiar to a particular industry.

Accounting in the idiosyncratic context of a hotel contract would appear to present some particular challenges, not least, what happens when a dispute develops between hotel owner and operator with respect to whether a particular asset related expenditure should be capitalised. In addition, given the two parties involved, at what point in progressing an asset related purchase, particularly if it is a large purchase, is consensus sought with respect to whether the asset related expenditure is to be capitalised. One might expect that the power balance between the two contracting parties may play a significant role in connection with 
these issues. Case study methodology could be usefully applied in subsequent research to shed further light on these novel accounting challenges. Another potentially fruitful line of enquiry could be pursued by examining the hotel management contracting context from the perspective of widely recognised agency theory constructs such as information asymmetry, adverse selection and moral hazard. Adoption of a theoretical framework informed by these constructs could well yield valuable insights concerning hotel owner and operator behaviours. Further research could usefully be undertaken to quantitatively gauge the relative strength of the 22 earnings management motivations identified in Tables 2-5 in order to validate and extend the insights provided by this study. Such a research objective could be pursued by way of a mailed questionnaire survey. Finally, further research could build on this study by replicating the work across different countries, drawing on Hofstede's work on culture (see 2001, 2005). Hotel owners would likely find insights provided by such research to be helpful when considering a prospective investment in a new overseas market. Any reduction in barriers to entry will likely stimulate further investment in global hotel markets, which could serve to increase the overall size of the hotel industry on a worldwide basis (Allison, 2004).

It should be acknowledged that the reported interview findings suffer from the limitations generally associated with qualitative field research. These limitations include the degree of subjectivity that is bound to be invoked by researchers when conducting interviews and analysing qualitative data, and also the fact that the size of the sample precludes any confident generalisation of the findings to a wider population. While a compensatory factor in this study derives from the mixed methods approach deployed, it should be noted that not all of the issues addressed during the qualitative research phase were also addressed in the study's mailed questionnaire survey phase. With respect to the study's survey phase, confidence surrounding the generalisability of the reported findings would have been enhanced had a higher response rate been secured. Again, some compensation for this shortcoming can be seen to derive from the fact that the questionnaire survey findings are consistent with the study's qualitative data findings. It should also be acknowledged that the unit of analysis in the questionnaire survey was cast at the hotel general manager level. The general managers surveyed were asked to comment on the relative tendency of hotel owners and operators with respect to capitalising asset related expenditure. This places onus on the general managers' understanding of the actions of hotel owners and operators. While this shortcoming should be acknowledged, it is difficult to conceive of a party that is better placed 
than general managers to provide insights on management tendencies of both hotel owners and operators.

\section{References}

Abernethy, M. A., Chua, W. F., Luckett, P. F., \& Selto, F. H. (1999). Research in managerial accounting: Learning from others 'experiences'. Accounting and Finance, 39(1), 1-27.

Aherns, R., \& Dent, J. F. (1998). Accounting and organizations: Realizing the richness of field research. Journal of Management Accounting Research, 10, 1-39.

Akrivos, C., Ladkin, A., \& Reklitis, P. (2007). Hotel managers' career strategies for success. International Journal of Contemporary Hospitality Management, 19(2), 107-119.

Allison, S. (2004). Inward investment into the European hotel investment market. Journal of Retail \& Leisure Property, 4(1), 50-60.

Bailey, C. A. (1996). A Guide to Field Research. Thousand Oaks, CA: Sage.

Barberis, N., Shleifer, A., \& Vishny, R. (1998). A model of investor sentiment. Journal of Financial Economics, 49, 307-343.

Beaver, W. H., \& Engel, E. (1996). Discretionary behavior with respect to allowances for loan losses and the behavior of security prices. Journal of Accounting and Economics, 22, 177-206.

Birnberg, J. G., Shields, M. D., \& Young, S. (1990). The case for multiple methods in empirical research in management accounting (with an illustration from budget setting). Journal of Management Accounting Research, 2(Fall), 1-40.

Bowen, R. M., Noreen, E., \& Lacey, A. R. (1981). Determinants of the corporate decision to capitalize interest. Journal of Accounting and Economics, 3(2), 151-180.

Chan, L. K. C., Karceski, J., Lakonishok, J., \& Sougiannis, T. (2008). Balance sheet growth and the predictability of stock returns. University of Illinois Working Paper.

Chapman, C. S., Hopwood, A. G., \& Shields, M. D. (2007). Handbook of Management Accounting Research. Oxford: Elesvier.

Clikeman, P. M., Geiger, M. A., \& O'Connell, B. T. (2001). Student perceptions of earnings management: The effects of national origin and gender. Teaching Business Ethics, 5(4), 389-410.

Collier, P., \& Gregory, A. (1995). Investment appraisal in service industries: A field study analysis of the U.K. hotels sector. Management Accounting Research, 6(1), 33-57.

Contractor, F. J., \& Kundu, S. K. (1998). Modal choice in a world of alliances: Analyzing organizational forms in the international hotel sector. Journal of International Business Studies, 29(2), 325.

Cooper, M. J., Gulen, H., \& Schill, M. J. (2008). Asset growth and the cross-section of stock returns. The Journal of Finance, 63(4), 1609-1651.

Daniel, K., Hirshleifer, D., \& Subramanyam, A. (1998). Investor psychology and security market under-and-overreactions. Journal of Finance, 53, 1839-1885.

Dechow, P. M., \& Skinner, D. J. (2000). Earnings management: Reconciling the views of accounting academics, practitioners, and regulators. Accounting Horizons, 14(June), 235-250.

Denton, G. A., \& Yiankes, D. (2004). Planning and managing capital expenditures. In P. Beals \& G. A. Denton (Eds.), Hotel Asset Management: Principles and Practices. 
East Lansing, MI: University of Denver and American Hotel \& Lodging Educational Institute.

Dhaliwal, D., Heninger, W. G., \& Hughes II, K. E. (1999). The investment opportunity set and capitalization versus expensing methods of accounting choice. Accounting and Finance, 39(2), 151-176.

Dimou, I., Chen, J., \& Archer, S. (2003). The choice between management contracts and franchise agreements in the corporate development of international hotel firms. Journal of Marketing Channels, 10(3,4), 33-39.

Easterby-Smith, M., Thorpe, R., \& Lowe, A. (2002). Management Research: An Introduction (2nd ed.). London: Sage.

Eyster, J. J. (1993). The revolution in domestic hotel management contracts. Cornell Hotel and Restaurant Administration Quarterly, 34(1), 16.

Eyster, J. J. (1997). Hotel management contracts in the U.S.: Twelve areas of concern. Cornell Hotel and Restaurant Administration Quarterly, 38(3), 21-34.

Farlex. (2006). Debt-service coverage ratio. Retrieved October 6, 2006, from http://financial-dictionary.thefreedictionary.com/Debt-Service+Coverage+Ratio++ DSCR

Goddard, P., \& Standish-Wilkinson, G. (2002). Hotel management contract trends in the Middle East. Journal of Retail \& Leisure Property, 2(1), 66-71.

Guenther, D. A. (1994). Earnings management in response to corporate tax rate changes: Evidence from the 1986 Tax Reform Act. The Accounting Review, 69(1), 230-243.

Guilding, C. (2003). Hotel owner/operator structures: Implications for capital budgeting process. Management Accounting Research, 14(3), 179-199.

Guilding, C., \& Hargreaves, B. (2003). How hoteliers do their capital budgeting. Hospitality Review, 5(1), 45-49.

Healy, P. M. (1985). The effect of bonus schemes on accounting decisions. Journal of Accounting and Economics, 7, 85-107.

Healy, P. M., \& Wahlen, J. M. (1999). A review of the earnings management literature and its implications for standard setting. Accounting Horizons, 13(4), 365-384.

Hirshleifer, D., Kewei, H., Teoh, S. H., \& Yinglei, Z. (2004). Do investors overvalue firms with bloated balance sheets? Journal of Accounting and Economics, 38, 297-331.

Hofstede, G. (2001). Cultures Consequences: Comparing Values, Behaviors, Institutions, and Organizations Across Nations (2nd ed.). Thousand Oaks, CA: Sage.

Hofstede, G. (2005). Cultures and Organizations: Software of the Mind (2nd ed.). New York: McGraw-Hill.

Hotel Brokers International. (2001). Hotel Financing Segments 2001 Survey: Hotel Brokers International.

Hotel Brokers International. (2005). Hotel Financing Segments 2005 Survey: Hotel Brokers International.

Hyatt, T. A., \& Weihrich, S. G. (2005). Capitalized customer acquisition costs and earnings quality: A case study of PhotoWorks, Inc. Journal of Accounting Education, 23(2), 117-148.

ISHC. (2007). CapEx 2007: A study of capital expenditures in the hotel industry (pp. 1-98). Alexandria, VA: International Society of Hospitality Consultants.

Iyengar, R. J. (1999). Simultaneity of accounting choice and exploration expenditures in the oil and gas industry. Petroleum Accounting and Financial Management Journal, 18(1), 32-49.

Jackling, B., Cooper, B. J., Leung, P., \& Dellaportas, S. (2007). Professional accounting bodies' perceptions of ethical issues, causes of ethical failure and ethics education. Managerial Auditing Journal, 22(9), 928-944. 
Jensen, M., \& Meckling, W. (1976). Theory of the firm: Managerial behaviour, agency costs and ownership structure. Journal of Financial Economics, 3(October), 305-360.

Jonas, H. (1979). Das Prinzip Verantwortung. Franfurt am Main: Insel Verlag.

Jonas, H. (1984). The Imperative of Responsibility. Chicago and London: Chicago University Press.

Kamran, A., \& Haim, F. (2006). The value relevance of management's research and development reporting choice: Evidence from Australia. Journal of Accounting and Public Policy, 25(3), 231-264.

Landry, S., \& Callimaci, A. (2003). The effect of management incentives and cross-listing status on the accounting treatment of R\&D spending. Journal of International Accounting Auditing \& Taxation, 12(2), 131-152.

Lantz, J., \& Sahut, J. (2005). R\&D investment and the financial performance of technological firms. International Journal of Business, 10(3), 251-261.

Lavely, J. (1983). An analysis of the new asset-expensing option. Journal of Small Business Management, 21(3), 58-64.

Lee, B. B., Press, E., \& Choi, B. (2001). Capital assets and financial statement distortions. Competitiveness Review, 11(2), 57-74.

Lillis, A. M. (1999). A framework for the analysis of interview data from multiple field research sites. Accounting and Finance, 39, 79-105.

Linhart, P. B., \& Lebowitz, J. L. (1974). The choice between capitalizing and expensing under rate regulation. Bell Journal of Economics, 5(2), 406-412.

Lipson, M. L., Mortal, S., \& Schill, M. J. (2009). On the scope and drivers of the asset growth effect. Darden Business School Working Paper.

Loudder, M. L., \& Behn, B. K. (1995). Alternative income determination rules and earnings usefulness: The case of R\&D costs. Comtemporary Accounting Research, 12(1), 185206.

McNichols, M., \& Wilson, G. P. (1988). Evidence of earnings management from the provision for bad debts. Journal of Accounting Research (Supplement), 1-31.

Michelson, S. E., Jordan-Wagner, J., \& Wootton, C. W. (2000). The relationship between the smoothing of reported income and risk-adjusted returns. Journal of Economics and Finance, 24(2), 141-159.

Miles, M. B., \& Huberman, A. M. (1994). An Expanded Sourcebook: Qualitative Data Analysis (2nd ed.). Thousand Oaks, CA: Sage.

Mitra, S., \& Rodrigue, J. (2002). Discretionary accounting accruals: A methodological issue in earnings management research. Journal of Forensic Accounting, 3(2), 185-192.

Model, S. (2010). Bridging the paradigm divide in management accounting research: The role of mixed methods approaches. Management Accounting Research, 21(2), 124129.

Mukherjee, T. K., \& Henderson, G. V. (1987). The capital budgeting process: Theory and practice. Interfaces, 17(2), 78-90.

Nelson, M. W., Elliott, J. A., \& Tarpley, R. L. (2002). Evidence from auditors about managers' and auditors' earnings management decisions. The Accounting Review, 77(1), 175-202.

Nelson, M. W., Elliott, J. A., \& Tarpley, R. L. (2003). How are earnings managed? Examples from auditors. Accounting Horizons, 17(s-1), 17-36.

Neuman, W. L. (2003). Social Research Methods: Qualitative and Quantitative Approaches. Boston: Pearson.

Niehaus, H. B. (2008). Is it time to rebalance? Lodging Hospitality, 64(2), 46-48.

Noreen, E., \& Bowen, R. M. (1989). Tax incentives and the decision to capitalize or expense. Accounting Horizons, 3(1), 29-44. 
Phillips, P. (2003). Capital expenditure in hotel chains: Implications for corporate structure. University of Surrey School of Management Working Paper.

Pinkowski, C. (1995). Hotel capital expenditure: How much is enough? The Bottom Line, 10(5), 22-32.

Ransley, J., \& Ingram, H. (2000). Developing Hospitality Properties \& Facilities. Oxford: Elsevier Butterworth-Heinemann.

Ransley, J., \& Ingram, H. (2001). What is "good" hotel design? Facilities, 19(1/2), 79-90.

Roberts, E. S. (1999). In defence of the survey method: An illustration from a study of user information satisfaction. Accounting and Finance, 39, 53-77.

Ross, S., Westerfield, R. W., \& Jordan, B. D. (2001). Fundamentals of Corporate Finance (2nd ed.). Roseville, Australia: McGraw-Hill.

Rossman, G. B., \& Wilson, B. L. (1984). Numbers and words: Combining quantitative and qualitative methods in a single large-scale evaluation study. Evaluation Review, 8(5), 627-643.

Rossman, G. B., \& Wilson, B. L. (1991). Numbers and words revisited: Being "shamelessly eclectic". Evaluation Review, 15(5), 596-619.

Rushmore, S. (1998). Bucking the hospitality trend. Lodging Hospitality, 54(7), 30.

Rushmore, S. (2002). Hotel investments handbook, viewed 2 September 2011, http://www.hospitalitynet.org/news/4021216.search?query=chapter+20+hotel+manag ement+contracts+pdf

Saunders, M., Lewis, P., \& Thornhill, A. (2003). Research Methods for Business Students. Essex, England: Pearson Education Limited.

Schipper, K. (1989). Commentary on earnings management. Accounting Horizons (December), 91-102.

Schlup, R. (2004). Hotel management agreements: Balancing the interests of owners and operators. Journal of Retail \& Leisure Property, 3(4), 331-343.

Schmidgall, R. S., Damitio, J. W., Duffy, P. A., \& Singh, A. J. (1998). Capital vs. revenue expenditures: A survey of the lodging industry. The Bottom Line, 13(5), 14.

Schmidgall, R. S., Damitio, J. W., \& Singh, A. J. (1997). What is capital expenditure? How lodging-industry financial executives decide. Cornell Hotel and Restaurant Administration Quarterly, 38(4), 28-33.

Schuetze, W. (1993). What is an asset? Accounting Horizons (September), 66-70.

Scott, W. R. (2003). Financial Accounting Theory (3rd ed.). Canada, Toronto: Pearson Education Canada Inc.

Smith, M. (2003). Research methods in accounting. London: Sage.

Styles, A. K., \& Coe, T. L. (2001). Changes in accounting practices in the oil and gas industry during the 1990s. Petroleum Accounting and Financial Management Journal, 20(3), 1-27.

Sutton, R. I., \& Rafaeli, A. (1998). Untangling the relationship between displayed emotions and organizational sales: The case of convenience stores. Academy of Management Journal, 31(3), 461-487.

Tucker, J. W., \& Zarowin, P. A. (2006). Does income smoothing improve earnings informativeness? The Accounting Review, 81(1), 251-270.

Turner, M. J., \& Guilding, C. (2010a). Accounting for the furniture, fittings \& equipment reserve in hotels. Accounting and Finance, 50(4), 967-992.

Turner, M. J., \& Guilding, C. (2010b). Hotel management contracts and deficiencies in owner-operator capital expenditure goal congruency. Journal of Hospitality and Tourism Research, 34(4), 478-511. 
Tzovas, C. (2006). Factors influencing a firm's accounting policy decisions when tax accounting and financial accounting coincide. Managerial Auditing Journal, 21(4), 372-386.

USALI. (1996). Uniform Systems of Accounts for the Lodging Industry. Michigan: American Hotel \& Motel Association.

Watts, R. L. (1974). Accounting objectives. University of Rochester Working Paper.

Wolk, H. I., Dodd, J. L., \& Tearney, M. G. (2008). Accounting Theory: Conceptual Issues in a Political and Economic Environment (7th ed.). Los Angeles: Sage.

Yin, R. K. (2002). Case Study Research, Design, and Methods (3rd ed.). Newbury Park, CA: Sage.

Young, S. M. (1996). Survey research in management accounting: A critical assessment. In A. J. Richardson (Ed.), Research Methods in Accounting: Issues and Debates. Vancouver: The Canadian General Accountants Research Foundation.

Zimmer, I. (1986). Accounting for interest by real estate developers. Journal of Accounting and Economics, 8(1), 37-52.

Zsolnai, L. (2003). Decision making in multiple value perspectives. International Journal of Value - Based Management, 16(3), 281-290. 


\begin{tabular}{|c|c|c|}
\hline \multicolumn{3}{|c|}{$\begin{array}{c}\text { Table } 1 \\
\text { Divergent perspectives of hotel owners and operators }\end{array}$} \\
\hline Owners & Focus & Operators \\
\hline $\begin{array}{l}\text { Objective is to maximise return and } \\
\text { long-term asset value }\end{array}$ & Objective & $\begin{array}{l}\text { Objective is to maximise fees and } \\
\text { retention of assets under long-term } \\
\text { management control }\end{array}$ \\
\hline $\begin{array}{l}\text { Return is derived from net income } \\
\text { after debt service }\end{array}$ & Return & $\begin{array}{l}\text { Return is derived primarily from } \\
\text { fees determined by revenue and } \\
\text { gross operating profit }\end{array}$ \\
\hline $\begin{array}{l}\text { Risk arises through a decline in asset } \\
\text { value }\end{array}$ & Risk & $\begin{array}{l}\text { Risk arises through loss of income } \\
\text { and damage to reputation }\end{array}$ \\
\hline $\begin{array}{l}\text { Value is derived from refinancing or } \\
\text { sale of asset }\end{array}$ & Value & $\begin{array}{c}\text { Value derives from adding to brand } \\
\text { worth and broadening system } \\
\text { overhead allocation }\end{array}$ \\
\hline
\end{tabular}

\footnotetext{
${ }^{5}$ The original version of this table by Ransley and Ingram was published in Developing Hospitality Properties \& Facilities, Copyright (c) Elsevier 2000.
} 


\begin{tabular}{|c|c|c|}
\hline \multicolumn{3}{|c|}{$\begin{array}{c}\text { Table } 2 \\
\text { Owner motivations to capitalise asset related expenditure }\end{array}$} \\
\hline $\begin{array}{l}\text { Description of } \\
\text { motivation }\end{array}$ & $\begin{array}{c}\text { Perceived } \\
\text { strength of } \\
\text { motivation } \\
\end{array}$ & Generic consolidation of interviewees' views \\
\hline $\begin{array}{l}\text { To bloat the balance } \\
\text { sheet. }\end{array}$ & Weak & $\begin{array}{l}\text { The market is sufficiently sophisticated to recognise } \\
\text { balance sheet bloating. Properties tend to be valued } \\
\text { by professional valuers who are not naïve. }\end{array}$ \\
\hline $\begin{array}{l}\text { To prevent operator } \\
\text { overbuilding. }\end{array}$ & Moderate & $\begin{array}{l}\text { Interviewees felt that as granting funding beyond } \\
\text { the FF\&E reserve is at the owner's discretion, some } \\
\text { owners are motivated to treat asset expenditure as } \\
\text { FF\&E capital expenditure in order to limit } \\
\text { operators' capacity to fund overbuilding through a } \\
\text { large FF\&E reserve account balance. }\end{array}$ \\
\hline $\begin{array}{l}\text { To satisfy debt } \\
\text { covenants to prevent } \\
\text { foreclosure on the } \\
\text { property. }\end{array}$ & Moderate & $\begin{array}{l}\text { Capitalising can assist in satisfying debt covenants, } \\
\text { but capitalising an amount of, say, } \$ 50,000 \text { on a } \\
\text { balance sheet of, say, } \$ 300 \text { million would be } \\
\text { relatively insignificant. The strength of this } \\
\text { motivation is dependent on the size of the hotel and } \\
\text { quantum of expenditure to be capitalised. }\end{array}$ \\
\hline $\begin{array}{l}\text { To demonstrate to } \\
\text { potential buyers that } \\
\text { the hotel has recently } \\
\text { undergone a high } \\
\text { capital spending } \\
\text { programme. }\end{array}$ & Weak & $\begin{array}{l}\text { High asset related spending can increase long-term } \\
\text { income, which can increase selling price. However, } \\
\text { sophisticated buyers who engage a good valuer are } \\
\text { unlikely to have their valuation influenced by } \\
\text { balance sheet net book value. }\end{array}$ \\
\hline To smooth income. & Moderate & $\begin{array}{l}\text { By capitalising, an owner triggers a schedule of } \\
\text { depreciation deductions, which underscore any } \\
\text { income smoothing attempts. }\end{array}$ \\
\hline $\begin{array}{l}\text { New: To enhance } \\
\text { yields on the property. }\end{array}$ & Moderate & $\begin{array}{l}\text { Maintaining profits through capitalising can } \\
\text { increase yields, which are important in the } \\
\text { determination of a property's value. }\end{array}$ \\
\hline $\begin{array}{l}\text { New: To satisfy brand } \\
\text { standards and avoid } \\
\text { related termination } \\
\text { clauses in the } \\
\text { management contract. }\end{array}$ & Moderate & $\begin{array}{l}\text { Capitalising can demonstrate higher spending on } \\
\text { asset related expenditure, which might help an } \\
\text { owner to highlight an enhanced effort on their part } \\
\text { to maintain an operator's brand standards and } \\
\text { therefore avoid an operator invoking management } \\
\text { contract termination on the grounds of an owner } \\
\text { failing to meet an operator's brand standard. }\end{array}$ \\
\hline
\end{tabular}




\begin{tabular}{|l|l|l|}
\hline \multicolumn{2}{|c|}{ Owner motivations to expense asset related expenditure } \\
\hline \multicolumn{1}{|c|}{$\begin{array}{c}\text { Description of } \\
\text { motivation }\end{array}$} & $\begin{array}{l}\text { Perceived } \\
\text { strength of } \\
\text { motivation }\end{array}$ & \multicolumn{1}{|c|}{ Generic consolidation of interviewees' views } \\
\hline $\begin{array}{l}\text { To reduce GOP so as } \\
\text { to reduce the } \\
\text { operator's incentive } \\
\text { management fee. }\end{array}$ & Very strong & $\begin{array}{l}\text { Most interviewees felt that this is the strongest of } \\
\text { all owner motivations to expense asset related } \\
\text { expenditures. }\end{array}$ \\
\hline $\begin{array}{l}\text { To receive greater } \\
\text { taxation deductions. }\end{array}$ & Strong & $\begin{array}{l}\text { Owners see the tax shield associated with expensing } \\
\text { asset related expenditures as a significant benefit. }\end{array}$ \\
\hline $\begin{array}{l}\text { To demonstrate to } \\
\text { potential buyers that } \\
\text { the hotel requires low } \\
\text { capital spending to } \\
\text { maintain it in its } \\
\text { current condition. }\end{array}$ & Weak & $\begin{array}{l}\text { Ten to fifteen years ago this motivation would have } \\
\text { been moderately strong, but today buyers are more } \\
\text { sophisticated and few would not see through this. }\end{array}$ \\
\hline $\begin{array}{l}\text { To push the operator } \\
\text { into management } \\
\text { contract termination } \\
\text { default clauses for not } \\
\text { meeting budgetary } \\
\text { targets. }\end{array}$ & Strong & $\begin{array}{l}\text { Many hotel management contracts were found to } \\
\text { include a provision stating that if the operator fails } \\
\text { to achieve 80\% of budgeted GOP in two } \\
\text { consecutive years, then the owner has the right to } \\
\text { terminate the contract. Where there is a poor owner- } \\
\text { operator relationship, this motivation is strong. }\end{array}$ \\
\hline $\begin{array}{l}\text { New: To offset legal } \\
\text { responsibility for } \\
\text { repair and } \\
\text { maintenance projects } \\
\text { to the operator. }\end{array}$ & Moderate & $\begin{array}{l}\text { Interviewees felt that for assets requiring significant } \\
\text { repairs and maintenance, this motivation can be } \\
\text { quite strong. }\end{array}$ \\
\hline
\end{tabular}




\begin{tabular}{|c|c|c|}
\hline \multicolumn{3}{|c|}{$\begin{array}{c}\text { Table } 4 \\
\text { Operator motivations to capitalise asset related expenditure }\end{array}$} \\
\hline $\begin{array}{l}\text { Description of } \\
\text { motivation }\end{array}$ & \begin{tabular}{|l|} 
Perceived \\
strength of \\
motivation \\
\end{tabular} & Generic consolidation of interviewees' views \\
\hline $\begin{array}{l}\text { To increase GOP and } \\
\text { receive higher } \\
\text { incentive management } \\
\text { fees. }\end{array}$ & Very strong & $\begin{array}{l}\text { Countering Table 3's reporting of owners having a } \\
\text { high motivation to expense in order to reduce } \\
\text { management fees, it was found that operators are } \\
\text { highly motivated to capitalise asset expenditures in } \\
\text { order to promote the reverse effect. }\end{array}$ \\
\hline $\begin{array}{l}\text { To increase GOP so as } \\
\text { to avoid management } \\
\text { contract termination } \\
\text { default clauses for not } \\
\text { meeting budgetary } \\
\text { targets. }\end{array}$ & Strong & $\begin{array}{l}\text { Interviewees felt that this motivation was strong, } \\
\text { especially in hotels reporting low levels of } \\
\text { profitability. }\end{array}$ \\
\hline To smooth income. & Moderate & $\begin{array}{l}\text { From the operator's perspective, it was noted that } \\
\text { an additional income smoothing incentive relates to } \\
\text { the income smoothing that derives from the } \\
\text { resultant depreciation cycle. }\end{array}$ \\
\hline $\begin{array}{l}\text { New: To offset legal } \\
\text { responsibility for } \\
\text { capital projects to the } \\
\text { owner. }\end{array}$ & Moderate & $\begin{array}{l}\text { Interviewees tended to view this motivation as } \\
\text { moderately significant. }\end{array}$ \\
\hline
\end{tabular}




\begin{tabular}{|l|l|l|}
\hline \multicolumn{2}{|c|}{ Operator motivations to expense asset related expenditure } \\
\hline \multicolumn{1}{|c|}{$\begin{array}{c}\text { Description of } \\
\text { motivation }\end{array}$} & $\begin{array}{l}\text { Perceived } \\
\text { strength of } \\
\text { motivation }\end{array}$ & \multicolumn{1}{|c|}{ Generic consolidation of interviewees' views } \\
\hline $\begin{array}{l}\text { The FF\&E reserve } \\
\text { balance is insufficient } \\
\text { to fund FF\&E } \\
\text { expenditure requisite } \\
\text { to maintaining a } \\
\text { property in good } \\
\text { working order. }\end{array}$ & Moderate & $\begin{array}{l}\text { Interviewees felt that this will be strong in hotels } \\
\text { with a low FF\&E reserve balance and where an } \\
\text { owner is resistant to additional FF\&E funding. }\end{array}$ \\
\hline $\begin{array}{l}\text { To leave more FF\&E } \\
\text { reserve for financing } \\
\text { asset replacements. }\end{array}$ & Moderate & $\begin{array}{l}\text { FF\&E reserve contribution levels are generally set } \\
\text { too low, so this is a technique commonly applied by } \\
\text { operators, especially where an owner is resistant to } \\
\text { additional FF\&E funding. }\end{array}$ \\
\hline $\begin{array}{l}\text { To bypass the need to } \\
\text { gain owner approval } \\
\text { for FF\&E expenditure. }\end{array}$ & Moderate & $\begin{array}{l}\text { This motivation is seen more in hotels where there } \\
\text { is a high propensity for urgent replacement of assets } \\
\text { and particularly in cases where the owner asset } \\
\text { approval process is lengthy. }\end{array}$ \\
\hline $\begin{array}{l}\text { To gain } \\
\text { reimbursement for } \\
\text { repairs and } \\
\text { maintenance expense. }\end{array}$ & Moderate & $\begin{array}{l}\text { This can be a strong factor in those hotels where the } \\
\text { management contract stipulates that the operator is } \\
\text { to be reimbursed for repair and maintenance } \\
\text { expenditure. }\end{array}$ \\
\hline $\begin{array}{l}\text { To manipulate GOP } \\
\text { between maximum } \\
\text { and minimum } \\
\text { thresholds to enhance } \\
\text { higher incentive } \\
\text { management fees in } \\
\text { future periods. }\end{array}$ & Moderate & $\begin{array}{l}\text { The motivation to minimise GOP in periods that are } \\
\text { likely to have no GOP was found to be very } \\
\text { common. The motivation to minimise GOP where } \\
\text { maximum thresholds are achieved, however, is } \\
\text { much less common due to these targets being set at } \\
\text { very high levels. }\end{array}$ \\
\hline $\begin{array}{l}\text { To avoid seeking } \\
\text { owner approval to } \\
\text { exceed budgetary } \\
\text { limits. }\end{array}$ & Moderate & $\begin{array}{l}\text { The interviewees felt that this motivation can be } \\
\text { quite strong, particularly in hotels where the owner } \\
\text { has developed a track record suggesting high } \\
\text { resistance to capital expenditure. }\end{array}$ \\
\hline
\end{tabular}




\begin{tabular}{|l|c|c|c|c|}
\hline \multicolumn{5}{|c|}{ Table 6 } \\
& \multicolumn{2}{|c|}{ Country } & & \\
\hline & $\begin{array}{c}\text { Australia } \\
(\boldsymbol{n})\end{array}$ & $\begin{array}{c}\text { New Zealand } \\
(\boldsymbol{n})\end{array}$ & $\begin{array}{c}\text { Total } \\
(\boldsymbol{n})\end{array}$ & $\begin{array}{c}\text { \% of total } \\
\text { responses }\end{array}$ \\
\hline First mailing & 55 & 28 & $\mathbf{8 3}$ & $\mathbf{4 1 . 5 \%}$ \\
\hline Second mailing & 36 & 11 & $\mathbf{4 7}$ & $\mathbf{2 3 . 5 \%}$ \\
\hline Industry distribution & 41 & 10 & $\mathbf{5 1}$ & $\mathbf{2 5 . 5 \%}$ \\
\hline Emailing distribution & 10 & 6 & $\mathbf{1 6}$ & $\mathbf{8 . 0 \%}$ \\
\hline Telephone & 3 & 0 & $\mathbf{3}$ & $\mathbf{1 . 5 \%}$ \\
\hline Total number of responses & 145 & 55 & $\mathbf{2 0 0}$ & $\mathbf{1 0 0 \%}$ \\
\hline Total number in sample & 437 & 184 & $\mathbf{6 2 1}$ & \\
\hline \multicolumn{1}{|c|}{ Total response rate } & $33.18 \%$ & $29.89 \%$ & $\mathbf{3 2 . 2 1 \%}$ & \\
\hline $\begin{array}{l}\text { Hotels with a management } \\
\text { contract }\end{array}$ & $\mathbf{8 5}$ & $\mathbf{1 6}$ & $\mathbf{1 0 1}$ & $\mathbf{5 0 . 5 \%}$ \\
\hline
\end{tabular}

Table 7

Summary statistics yielded by survey questions

\begin{tabular}{|l|c|c|}
\hline \multicolumn{1}{|c|}{ Question focus } & Mean & $\begin{array}{c}\text { Standard } \\
\text { deviation }\end{array}$ \\
\hline Extent hotel owner seeks to capitalise asset related expenditures & 3.94 & 1.66 \\
\hline Extent hotel operator seek to capitalise asset related expenditures & 4.54 & 1.47 \\
\hline
\end{tabular}

Responses provided on a Likert scale where '1' corresponds to 'not at all' and '7' corresponds to 'to a large' extent 